\title{
GAMBARAN PENGETAHUAN MASYARAKAT TENTANG RUMAH TANGGA SEHAT DI RT 01 RW 06 KELURAHAN KAMPUNG MELAYU SUKAJADI PEKANBARU
}

\author{
Wiwik Norlita, Tri Siwi KN, Julianti \\ Program Studi D III Keperawatan, FMIPA. \& Kesehatan UMRI \\ Email: trisiwiningrum@yahoo.com
}

\begin{abstract}
ABSTRAK
Tujuan penelitian ini adalah untuk mengetahui gambaran pengetahuan masyarakat tentang rumah tangga sehat. Desain penelitian yang digunakan adalah deskriptif dengan menggunakan teknik simple random sampling. Penelitian dilaksanakan pada 14-25 Maret 2011 di RT 04 RW 06 Kelurahan Kampung Melayu Sukajadi Pekanbaru dengan jumlah sampel 50 responden Teknik pengumpulan data menggunakan kuesioner dan analisa data yang digunakan adalah univariate. Hasil penelitian menunjukkan bahwa gambaran pengetahuan responden tentang rumah tangga sehat di RT 04 RW 06 Kelurahan Kampung Melayu Sukajadi Pekanbaru mayoritas dalam kategori baik sebanyak 45 responden $(90 \%)$, dalam kategori cukup 4 responden ( $8 \%)$ dan dalam kategori kurang 1 responden $(2 \%)$. Berdasarkan hasil penelitian tersebut perlu adanya motivasi untuk meningkatkan kesadaran masyarakat tentang penerapan rumah tangga sehat agar tercipta individu dan keluarga yang sehat.
\end{abstract}

Kata kunci: Pengetahuan Masyarakat, Rumah Tangga Sehat, Indikator

\section{PENDAHULUAN}

Rumah tangga sehat merupakan rumah tangga yang berperilaku sehat, yang selalu mempraktikkan perilaku hidup bersih dan sehat, serta ikut berperan aktif dalam gerakan - gerakan peningkatan kesehatan masyarakat (Depkes, 2006).

Kesadaran atas penerapan rumah tangga sehat di negara maju memang jauh lebih tinggi dibandingkan dengan di negara berkembang. Di negara maju seperti Amerika Serikat terlihat bahwa penyakit menular tidak lagi menjadi masalah, mereka memiliki umur yang lebih panjang. Kunci perbedaannya terletak pada tingkat kesejahteraan dan faktor gaya hidup sehat. Sedangkan di Indonesia menurut data Riset Kesehatan Dasar (RISKESDAS) tahun 2007 prevalensi nasional rumah tangga sehat adalah 38,7 persen sebanyak 22 provinsi dan menurut Sensus Kesehatan Nasional
(SUSENAS) tahun 2004 secara keseluruhan tidak ada rumah tangga yang memenuhi 10 indikator sehat, sedangkan rumah tangga yang memiliki 9 indikator rumah tangga sehat atau lebih hanya 0,2 persen dan yang memiliki 8 indikator rumah tangga sehat atau lebih hanya 3 persen. Hasil survey rumah tangga sehat di kota pekanbaru memiliki persentase paling rendah $(50.80 \%)$ dari tatanan perilaku hidup bersih lainnya.

Berdasarkan pengamatan yang dilakukan oleh peneliti di RT 04 RW 06 Kelurahan Kampung Melayu Sukajadi Pekanbaru terhadap lingkungan tempat penelitian, ada beberapa rumah yang kurang terawat, masih tampak adanya sampah-sampah yang berserakan di sekitar selokan, selain itu lokasi penelitian berdekatan dengan tempat tinggal peneliti sehingga membantu memudahkan dalam proses penelitian. 


\section{METODOLOGI PENELITIAN}

Jenis penelitian yang digunakan dalam penelitian ini adalah deskriptif, Sampel diambil dengan cara menggunakan teknik simple random sampling dengan jumlah responden 50 orang.

Dalam analisa data mengukur pengetahuan menggunakan analisa secara manual (univariate). Analisa data yang dilakukan hanya melihat hasil perhitungan frekuensi dan persentase hasil dari penelitian yang nantinya dapat dipergunakan sebagai tolak ukur untuk pembahasan dan menarik kesimpulan. dengan melihat persentase data yang dikumpulkan dan sajian dalam bentuk tabel frekuensi dengan rumus sebagai berikut:

$$
P=\frac{F}{N} \times 100 \%
$$

Keterangan:

$\mathrm{P} \quad=$ Persentase

$\mathrm{F} \quad=$ Frekuensi jumlah jawaban benar

$\mathrm{N}=$ Jumlah pertanyaan

Hasil perhitungan persentase dimasukkan dalam kriteria standard objektif menurut Nursalam (2003), sebagai berikut:

Baik : 76-100\%

Cukup : $56-75 \%$

Kurang: $<56 \%$

\section{HASIL DAN PEMBAHASAN}

\section{A. Karakteristik Responden}

Tabel 1.

Distribusi Frekuensi Responden Berdasarkan Umur Di RT 04 RW 06 Di Kelurahan Kampung Melayu Sukajadi Pekanbaru Maret 2011

\begin{tabular}{cccc}
\hline No & Umur & Frekuensi & $\begin{array}{c}\text { Persentase } \\
(\boldsymbol{\%})\end{array}$ \\
\hline 1 & $\leq 20$ & 2 & 4 \\
2 & $21-30$ & 20 & 40 \\
3 & $31-40$ & 13 & 26 \\
4 & $41-50$ & 6 & 12 \\
5 & $\leq 50$ & 9 & 18 \\
\hline & Total & $\mathbf{5 0}$ & $\mathbf{1 0 0} \%$ \\
\hline
\end{tabular}

Tabel 2.

Distribusi Frekuensi Responden Berdasarkan Jenis Kelamin Di RT 04 RW 06 Di Kelurahan Kampung Melayu Sukajadi Pekanbaru Maret 2011

\begin{tabular}{cccc}
\hline No & $\begin{array}{c}\text { Jenis } \\
\text { Kelamin }\end{array}$ & Frekuensi & $\begin{array}{c}\text { Persentase } \\
(\boldsymbol{\%})\end{array}$ \\
\hline 1 & Laki-laki & 19 & 38 \\
2 & Perempuan & 31 & 62 \\
\hline & Total & $\mathbf{5 0}$ & $\mathbf{1 0 0 \%}$ \\
\hline
\end{tabular}

Tabel 3.

Distribusi Frekuensi Responden Berdasarkan Pendidikan Di RT 04 RW 06 Di Kelurahan Kampung Melayu Sukajadi Pekanbaru Maret 2011

\begin{tabular}{cccc}
\hline No & Pendidikan & Frekuensi & $\begin{array}{c}\text { Persentase } \\
(\mathbf{\%})\end{array}$ \\
\hline \multirow{2}{*}{1} & SD & 5 & 10 \\
2 & SMP & 5 & 10 \\
3 & SMA & 24 & 48 \\
4 & Perguruan & 16 & 32 \\
\hline & Tinggi & & $\mathbf{1 0 0} \%$ \\
\hline
\end{tabular}

Tabel 4.

Distribusi Frekuensi Responden Berdasarkan Pekerjaan Di RT 04 RW 06 Di Kelurahan Kampung Melayu Sukajadi Pekanbaru Maret 2011

\begin{tabular}{llcc}
\hline No & Pekerjaan & Frekuensi & $\begin{array}{c}\text { Persentase } \\
(\boldsymbol{\%})\end{array}$ \\
\hline 1 & Wiraswasta & 24 & 48 \\
2 & PNS & 8 & 16 \\
3 & IRT & 15 & 30 \\
4 & Honor & 3 & 6 \\
\hline & Total & $\mathbf{5 0}$ & $\mathbf{1 0 0 \%}$ \\
\hline
\end{tabular}

Tabel 5.

Distribusi Frekuensi Responden Berdasarkan Informasi Yang Diterima Tentang Rumah Tangga Sehat di RT 04 RW 06 Di Kelurahan Kampung Melayu Sukajadi Pekanbaru Maret 2011

\begin{tabular}{cccc}
\hline No & $\begin{array}{c}\text { Informasi } \\
\text { Yang } \\
\text { Pernah } \\
\text { Diperoleh }\end{array}$ & Frekuensi & $\begin{array}{c}\text { Persentase } \\
(\%)\end{array}$ \\
\hline 1 & Ya & 34 & 68 \\
2 & Tidak & 16 & 32 \\
\hline & Total & $\mathbf{5 0}$ & $\mathbf{1 0 0 \%}$ \\
\hline
\end{tabular}

Tabel 6.

Distribusi Frekuensi Responden Berdasarkan Sumber Informasi Yang Diterima Responden Tentang Rumah

Tangga Sehat Di RT 04 RW 06 Di Kelurahan Kampung Melayu Sukajadi Pekanbaru Maret 2011

\begin{tabular}{cccc}
\hline No & $\begin{array}{c}\text { Sumber } \\
\text { Infomasi }\end{array}$ & Frekuensi & $\begin{array}{c}\text { Persentase } \\
(\%)\end{array}$ \\
\hline
\end{tabular}




\begin{tabular}{llcc}
\hline 1 & Media & 10 & 29,41 \\
2 & Elektronik & 11 & 32,35 \\
3 & Media Cetak & 12 & 35,30 \\
4 & Tenaga & 1 & 2,94 \\
& Kesehatan & & \\
& Tetangga & & $\mathbf{1 0 0 \%}$ \\
\hline
\end{tabular}

\section{B. Data Pengetahuan}

\section{Tabel 7.}

Distribusi Frekuensi Pengetahuan Responden Tentang Rumah Tangga Sehat Di RT 04 RW 06 Di Kelurahan Kampung Melayu Sukajadi Pekanbaru Maret 2011

\begin{tabular}{llcc}
\hline No & Kategori & Frekuensi & $\begin{array}{c}\text { Persentase } \\
(\mathbf{\%})\end{array}$ \\
\hline 1 & Baik & 45 & 90 \\
2 & Cukup & 4 & 8 \\
3 & Kurang & 1 & 2 \\
\hline & Total & $\mathbf{5 0}$ & $\mathbf{1 0 0 \%}$ \\
\hline
\end{tabular}

\section{Pembahasan}

Berdasarkan hasil penelitian pada masyarakat di RT 04 RW 06 Kelurahan Sukajadi Pekanbaru didapatkan bahwa umur responden mayoritas 21-30 tahun sebanyak 20 responden (40\%). Hal ini didukung oleh teori Hurlock (1998) yang dikutip oleh Permata (2002) bahwa umur 20-25 tahun merupakan umur yang cepat menganalisa atau menerima sesuatu informasi dibanding dengan umur pertengahan menunjukkan kurangnya daya serap dalam menerima informasi yang disampaikan baik dari media massa, media cetak maupun media elektronik.

Selain umur responden, peneliti menduga tingkat pendidikan responden juga mempengharuhi hasil penelitian. Berdasarkan hasil penelitian pada responden didapatkan bahwa tingkat pendidikan responden mayoritas SMA yaitu sebanyak 24 responden (48\%).

Menurut Permata (2002), mengatakan bahwa orang yang berpendidikan lebih tinggi memiliki kesempatan yang lebih luas untuk terpajan dengan informasi dan akan memiliki pengetahuan yang lebih tinggi dibandingkan dengan mereka yang tidak berpendidikan. Hal yang sama didukung oleh teori Berg (2000), mengatakan bahwa latar belakang pendidikan unsur penting yang mempengaruhi pendidikan karena dengan pendidikan yang tinggi diharapkan pengetahuan yang dimilikinya menjadi lebih baik.

\section{Menurut Notoatmodjo} mengemukakan bahwa tingkat pendidikan akan mempengaruhi perilaku seseorang akan pola hidup terutama dalam motivasi untuk berperan dalam pembangunan kesehatan. Hal ini didukung oleh pendapat Fudjartanto (2002), motivasi merupakan suatu usaha untuk meningkatkan kegiatan dalam mencapai suatu tujuan.

Pendidikan merupakan salah satu faktor yang mempengaruhi cara pandang seseorang tentang hidup dalam hal ini kesehatan. Seorang yang memiliki tingkat pendidikan yang tinggi cenderung terpajan dengan sumber informasi.. Semakin banyak seseorang terpajan dengan informasi maka semakin baiklah pengetahuannya, sebaliknya semakin kurang informasi yang diperoleh seseorang maka kurang pengetahuannya.

Berdasarkan analisis peneliti semakin banyak informasi yang menambah pengetahuan responden akan menimbulkan kesadaran yang akan mengubah perilaku sesuai pengetahuan yang dimilikinya.

\section{KESIMPULAN}

Berdasarkan Dari hasil penelitian yang dilakukan di RT 04 RW 06 Kelurahan Kampung Melayu Sukajadi Pekanbaru pada tanggal 14-25 maret 2011 pada 50 responden dapat disimpulkan bahwa pengetahuan responden tentang rumah tangga sehat di RT 04 RW 06 kelurahan kampung melayu sukajadi pekanbaru yang terbanyak adalah dalam kategori baik yaitu 
sebanyak 45 responden (90\%). Akan tetapi berdasarkan wawancara terhadap responden, penerapan indikator rumah tangga sehat belum maksimal dilaksanakan dalam kegiatan sehari-hari. Hal ini disebabkan karena rendahnya motivasi serta kesadaran responden terhadap penerapan rumah tangga sehat.

\section{DAFTAR PUSTAKA}

Depkes RI, (2006), Buku Saku Rumah Tangga Sehat dengan PHBS, Pusat Promosi Kesehatan: Jakarta

Mulyo. (2008). Definisi dan Jenis-Jenis Pengetahuan. Diperoleh pada tanggal 30 desember 2010 di http://info.gexcess.com/id/online/Pengertian

Pengetahuan.info.

(2003). Ilmu Kesehatan Masyarakat: PrisipPrinsip Dasar. Jakarta: Rineka Cipta

(2005). Metodologi Penelitian Kesehatan.
Jakarta: Rineka Cipta

Nursalam. (2003). Konsep dan Penerapan Ilmu Keperawatan. Jakarta: Rineka Cipta

Permata (2002). Hubungan pendidikan, pengetahuan kesehatan maternal dan pendapatan dengan efektivitas gerakan sayang ibu dalam meningkatkan cakupan persalinan oleh tenaga kesehatan

RISKESDAS.(2007). Perilaku hidup bersih dan sehat. Diperoleh pada tanggal 21 Desember 2010 di www. Docstoc.com/RISKESDAS-Nasional2007

Susenas (2004). Prilaku Hidup Bersih Dan Sehat Dalam Tatanan Rumah Tangga dinkes-

sulsel.go.id/new/.../kmk\%20indikator\% 202010\%201202-2001.pdf) 